\title{
Politics, Society and Culture in Latin America
}

\section{Introduction}

\section{Stanisław Kosmynka}

(iD) https://orcid.org/0000-0003-4131-4762

University of Lodz

Faculty of International and Political Studies

Department of Latin America and Comparative Studies e-mail:skosmynka@uni.lodz.pl

\section{Michał Stelmach}

(iD) https://orcid.org/0000-0001-5857-6262

University of Lodz

Faculty of International and Political Studies

Department of Latin America and Comparative Studies e-mail: michal.stelmach@uni.lodz.pl 
The articles in this volume of International Studies cover various topics from the field of Latin American studies. They address important and current issues regarding transnational crime and security, socio-political processes, inter-state and state-church relations, migration processes, different dimensions and images of conflicts (political, social, regional ones) as well as the relationship between art and politics in Latin America. The complexity of contemporary political, social and cultural phenomena in Latin America requires an interdisciplinary approach, which is evident both in individual texts and the wide range of topics undertaken by the Authors.

The greatest challenge for most Latin American countries is the fight against organised criminal groups, whose activities destabilise the internal situation, destroying weak and unconsolidated democratic institutions, negatively affecting economies and leaving an imprint of criminal violence on the societies living in permanent fear, while at the same time seriously threatening international security. Currently, we can indicate several Latin American regions where organised crime is developing dynamically: Mexico and Central America; two border areas: Brazil, Venezuela and Colombia; and the other one: Brazil, Paraguay and Argentina, known as the Tri-Border Area (TBA). Stanisław Kosmynka analyses the forms and mechanisms of organised crime in the TBA, showing the latest trends in trafficking in human beings, arms and drugs. He also evaluates security strategies aimed at combating petty and organised crime in the border area of Brazil, Paraguay and Argentina.

In the $21^{\text {st }}$ century, despite democratisation processes, armed forces remain an important player on the political scene of many Latin American countries. Michat Stelmach analyses the forms of political involvement of the servicemen in politics and the role and position of armed forces in the unconsolidated democratic systems of Latin American countries. He draws attention to the phenomenon of electoral successes of retired service members who at the turn of the $20^{\text {th }}$ and $21^{\text {st }}$ century won the presidential race in several countries of the region, as well as the problem of militarisation of political parties. The subject of research is also contemporary civil-military relations. The Author discusses the process of establishing democratic control over the armed forces, showing hardships associated with demilitarisation of national defence ministries as well as establishment and implementation of parliamentary control over the army and redefinition of the army's functions in the conditions of democracy and peace.

Governments of many Latin American countries are currently facing a difficult challenge of accounting for the period of violence and dictatorships. Committees of truth functioning in the transitional periods determined the causes and mechanisms of human rights violations during the period of the military regime and internal armed conflicts. However, only a small percentage of perpetrators have been held criminally responsible. In many cases, the armed forces still effectively 
defend their members against bearing responsibility, and justify mass murders, disappearance and torture as acting in a state of necessity, in defence of society against the internal enemy: the leftist guerrilla. Under these circumstances, it is difficult to speak of justice and genuine national reconciliation. The difficult issue of accounting for the crime of cruelty is discussed in Joanna Pietraszczyk-Sękowska's article that focuses on the phenomenon of return migration and search for missing persons (desaparecidos) during the war. The Author discusses memory policy in Peru, drawing attention to different narrations about the course of military operations and pointing out the challenges associated with the search, exhumation and examination of remains of desaparecidos.

Next article is devoted to international migration. Katarzyna Dembicz shares the results of research on contemporary Cubans' migration. She focuses on two aspects of the phenomenon: the migration of Cubans to the United States through Mexico and the Central American countries, and return migration to Cuba. The Author undertakes a polemic with the myth of Cuban refugees, pointing out social, economic and political factors conditioning the latest migration wave to the USA from 2014-2017, and then introduces the scale of the phenomenon and the migration routes. Moreover, she draws attention to the changes in Cuban social and migration policy, aiming at limiting mass emigration and encouraging members of the Cuban diaspora in the United States to return to the country.

Marta Osuchowska discusses the relations between Argentina and the Holy See in the $20^{\text {th }}$ century. She presents different dimensions and dynamics of changes in bilateral relations from a historical perspective in the period before and after signing the concordat in 1966 . The Author analyses the concordat content as well as the consequences of implementing its provisions into the national legal system; she also discusses the relations between the state and the church in Argentina.

Next article focuses on the issue of separatism in Latin America. Tomasz Rudowski and Piotr Sieniawski examine political and social determinants of separatism and review historical and contemporary separatist movements in Latin Ameri$\mathrm{ca}$. They assume a comparative perspective by juxtaposing Catalan nationalism and separatism with secessionist tendencies in the southern states of Brazil. The authors' priority is to determine the reasons for low activity and weakness of separatist movements in the ethnically and culturally diverse region of Latin America.

Ewa Kubiak explores the relationship between art and politics in the text dedicated to the proclamation of king Ferdinand VI in Cusco (Peru), which took place on 23 September 1747. The Author analyses the celebrations associated with the royal family as a part of the Crown's policy, examining the artistic aspects of the ceremony and detailing the social and political context of the celebration, while paying attention to the manifestations of independence and the rich imperial tradition in the pre-Hispanic period. 
In the last article in this volume, Stanisław Iwaniszewski discusses the achievements of the Polish Latin Americanists, focusing on archeoastronomy, which remains a part of broadly understood cultural astronomy. The article focuses on the interactions that took place between groups of people and the phenomena observed in the sky in the archaeological past.

Last but not least, Krystian Darmach considers the mechanisms and images of the conflict growing in recent years between the needs of mass tourism and the local urban environment in Latin American cities, and outside the region. In an academic essay he presents a wide range of problems related to the transformation of urban space and its adaptation to the requirements of the tourist market and resistance of permanent city residents. 